\title{
JUSTICE AND ECOLOGY: FROM A PERSPECTIVE OF POLITICAL PHILOSOPHY'
}

Xiaomeng ZHANG,

PhD, Renmin University of China,

Beijing, China

e-mail: xiaomeng@ruc.edu.cn; zxmtsinghua@163.com

The paper analyzes the crucial issue of ecology from the perspective of political philosophy, indicating that the high speed of development of industrial civilization has accelerated the improvement of productivity on one hand, and reconstructed peoples' consumption demand and ability on the other hand. People immersed in their selfindulgence in the process of practices in changing nature, the activities of whom inevitably resulted in the alienation of human being and the over-exploitation of ecology. Ecological Marxism uses the theory of justice to explore the fundamental relation of capitalist system and ecological crisis, redefining the dual value dimensions of human and nature so as to construct a new framework of social justice. By analyzing ecological justice with the dimensions of technology, economy and politics, a conclusion has been reached on the necessary underlying correlation between the capitalist system and ecological crisis- the inherent and internal contradiction within capitalism would consequentially endanger the construction of the principles on ecological justice. Therefore, it is in urgent need to create a comprehensive new pattern of justice, requiring an overall consideration on ecological, economic and social justice to reform the existing political system and world order. Meanwhile, it is necessary to evoke the transformation of the values, so as to establish an ecological civilization in accordance with the principle of justice, as well as the harmonious coexistence between human and nature.

Keywords: justice; ecology; capitalism; Marxism; human and nature; reform

JEL classifications: Q5; B51; P16

\section{СПРАВЕААИВОСТЬ И ЭКОАОГИЯ С ТОЧКИ ЗРЕНИЯ ПОАИТИЧЕСКОЙ ФИАОСОФИИ}

\author{
Сяомин ЧЖАН, \\ $\mathrm{PhD}$, Китайский народный университет, \\ Пекин, Китай, \\ e-mail: xiaomeng@ruc.edu.cn; zxmtsinghua@163.com
}

\footnotetext{
${ }^{1}$ The paper is supported by the National Social Science Foundation of China (Grant No. 13CKS006) and RUC-UNIGE joint seed fund (the fundamental research funds for the central universities, and the research funds of Renmin University of China, Grant No. 16XNQ019).

(c) Сяомин Чжан, 2016
} 
В статье содержится анализ важнейшего вопроса - экологии - с точки зрения политической философии. Указывается на то, что стремительное развитие индустриальной цивилизации, с одной стороны, ускорило рост производительности, a, с другой стороны, изменило структуру потребительского спроса и возможностей потребления со стороны населения. Будучи поглощены стремлением удовлетворять свои желания, люди в своей практической деятельности оказывают воздействие на природу, что неизбежно ведет $к$ отчуждению человека и чрезмерной эксплуатации экосреды. Экологический марксизм апеллирует к теории справедливости для исследования фундаментальной взаимосвязи между капиталистической системой и экологическим кризисом, переопределяя представление о взаимосвязи человека с природой, $c$ тем чтобы заложить основы новой концепции социальной справедливости. Анализ экологической справедливости в координатах технологии, экономики и политики привел к выводу о неизбежности основополагающей взаимосвязи между капиталистической системой и экологическим кризисом - в связи с имманентно присущей капитализму внутренней противоречивостью, которая может поставить под угрозу построение принципов экологической справедливости. Таким образом, представляется необходимым формирование новой комплексной концепци справедливости, требующей всестороннего обсуждения в контексте экологической, экономической и социальной справедливости с целью реформирования существующей политической системы и мирового порядка. Не менее важным представляется также необходимость трансформации ценностей, которая может привести к образованию экологической цивилизации, построенной на принципах справедливости, а также гармоничного сосуществования человека и природы.

Ключевые слова: справедливость; экология; капитализм; марксизм; человек и природа; реформа

Nowadays, ecology is not only seen as an issue relating to nature and environment, but also seen as a subject of civilization, which is crucial to the long-term existence of human being and the conservation of civilization. The principle of justice of the relation of human and nature within it is, on a deeper level, closely related to justice of the system.

\section{Justice of Ecological Philosophy}

The innovation of high technology and the revolution of the mode of production have paved the way to the high efficiency of the modernization of the society, ever since the industrial revolution. While people are enjoying the sweet fruits of productivity, they have to endure the by-products of the civilization of industry, severe degradation of environment and climate crisis as typical examples.

The rapid industrialization process and the fierce business competition have eroded the attitude of human being towards itself and nature. People's transformation of nature is accompanied with massive inflation of their material demands. The self-inflation has forced them into a new status of isolation: anthropocentrism. People exaggerate self-value and the power of practice in error, and then exploit with reckless abandon the planet to meet their increasing needs. The unlimited desire of people has constantly challenged and exceeded the limit of nature's bearing capacity. Someday nature will terminate the resources supply and gradually becomes the killer of human beings. It never occurs to us that we have lost our way, diverging from the original intention of development as a harmonious status of human and nature, until the ecological degradation has set the 
obstacles for the social development. In the course of unscrupulous transformation of the nature, the environment has been permanently damaged, meanwhile leading to the alienation of existence of human being.

A large number of well-known severe environmental pollution incidents have raised an alarm for the human being, prompting people to realize that the disaster of ecological environment has severely threatened the living of human. In the Los Angeles photochemical smog episode in the 1940s, more than 2500,000 cars have burned 700 tons of gasoline each day, venting approximately 1000 tons of hydrocarbons, 300 tons of Nitrogen 0xide and 700 tons of carbonic oxide. The chemical reaction induced by the emission resulted in the colored smog, which threatened the breathing of people and seriously affected the daily lives. In 1955, more than 400 old people over 65 have passed away dues to respiratory failure. The lost caused by air pollution was as high as 1500 million US dollars from 1950 to 1951. The London smog incident caused even more serious crisis of public health, which was an unavoidable disaster in the process of industrialization. The infamous smog and severe pollution have led to the death of over 8000 in two months, with the peak of 4000 death in five days. Water, as another type of largest public goods, is facing a similar tragic situation. The Minamata disease events in 1953 in Japan has drew global attention, when the poisonous waste water was discharged by local industrial enterprises into the bay, and then virulent chemicals accumulated in the sea and sea creatures resulted in the spasm and insanity of people by the complicated biologic chain. The most ironic and thought-provoking consequence was that even the cat raised by human being jumped into the sea to commit suicide because of eating fish that contains toxic chemicals. The cases mentioned above was the Butterfly Effect in ecological environment, which alerts that the global biologic chains are closely binding together, hence form a community within which people share interests and responsibilities in common. Otherwise the self-alienated irresponsible actions would result in great catastrophes about the final destiny of human being.

The deep reflection of human beings on environmental crisis results in the birth of ecological philosophy. As the environmental problems became serious, people began to realize that it is the crisis not only of industry, but also of values and of the civilization of human beings. Therefore, from the sixties in the $20^{\text {th }}$ century, the movement of climate politics emerged, concentrating on the environmental protection and the harmonious relations between human and nature. People established Green Party and other similar non-governmental organizations based on this idea and carried out a series of projects to protect ecosystem. In the social field, the initiatives of the environment protection are well received by citizens, which have further reconstructed the structure of social governance. The appeals of the civil society have drawn more and more attentions from the government in their legal collective actions and arrived at consensus on environmental issues between them. In a survey by Peking University in China, the environmental protests of Qidong and other City is ranking in the first place among all the issues of civil society in 2012. Climate politics rings the alarm and pushes human beings to rethink about the lifestyles they are accustomed to. In a word, it is a brand-new way to save eco-system in the post-industrial era.

The diverse climate politics reflect the universal pursuit of justice, which also lead the way of ecological movement and public policies. People are stepping out of the idea of egocentrism, and begin to think comprehensively about the justice of institutions, economy, society and eco-system. Every policy of environment protection presents justice, not only as an ethical support but also as a political issue, because the redistribution of resources behind the policy is always an important topic in politics.

\section{The Diverse Dimensions of Ecological Justice}

Today, people have arrived at the consensus that ecology, as the largest public goods, is the collective wealth and responsibility of human being. Ecological justice is closely 
related to justice of institution, economy and society. Ulrich Beck, the German sociologist, has reflected on the civilization of modern industry in the book Risk Society: Towards a New Modernity and named the modern industrial societies are "towards the volcano of civilization". Beck (1992) describes the phenomenon as "the interior furnishings of the civilizational world":

The destruction of nature, integrated into the universal circulation of industrial production, ceases to be "mere" destruction of nature and becomes an integral component of the social, political and economic dynamic. The unseen side effect of the societalization [Vergesellschaftung] of nature is the societalization of the destruction and threats to nature, their transformation into economic, social and political contradictions and conflicts. Violations of the natural conditions of life turn into global social, economic and medical threats to people- with completely new sorts of challenges to the social and political institutions of highly industrialized global society (p. 80).

Human and the nature is closely related and integrated as a whole, so that any damage of a single link would severely endanger the cycle of the causal chain.

On the basis of the consensus reached by ecological justice, there are two important questions that face us: What exactly trample on the principle of ecological justice? Whether or not it can become the hope for the salvation of ecological justice by eliminating the source of damage?

\section{Technical Dimension}

The answer to the first question might be the technological rationality. Technical innovation has tremendously enhanced the productivity and economic benefits, but it also increased people's capability and desire of changing the world. Due to the development of social division as well as the formalization of organizations, technological rationality is permeating into human behaviors deeply. Technology and capital that are supposed to be major medium of social interactions have become the aim of social interactions instead. The technology created by human beings prevents our development conversely. Herbert Marcuse (1971. P. 4) uses an equation to define the law of capitalist progress: technical progress = growing social wealth (the rising GNP!) = extended servitude. Continuously expanding demands lead to self-alienation of human beings, who carry on endless consumption and destruction to the ecological environment in a way of mechanized practice.

Karl Marx (1980) has indicated that the victories of art seem bought by the loss of character. At the same pace that mankind masters nature, man seems to become enslaved to other men or to his own infancy. Even the pure light of science seems unable to shine but on the dark background of ignorance. All our invention and progress seem to result in endowing material forces with intellectual life, and in stultifying human life into a material force. This antagonism between modern industry and science on the one hand, modern misery and dissolution on the other hand; this antagonism between the productive powers and the social relations of our epoch is a fact, palpable, overwhelming, and not to be converted (pp. 655-656).

Worship of technology and efficiency in modern society has made people heavily dependent upon and enslaved to the technological world. Modern society integrates our daily life into modern production systems, along with injection of new values by the deconstruction and reorganization of technology. In order words, technology as a medium has merged culture, politics and economy together into an omnipresent system. Technological rationality turns out to be a new ideology that controls and dominates people, profoundly intervening and shaping our cultural life. The egomaniac built based on technology believes that technology development can efficiently ease the pressures on the ecological environment and eliminate all of existing negative effects on ecological environment imposed by industrialization process. Admittedly, technological development and advancement promoted by basic values indeed solve certain ecological problems to some extent 
and avoid large-scale disasters. However, the ecological dilemma that deteriorates and expands gradually nowadays, as well as the negotiation challenges that United Nations and other agencies face on the issues of ecological environment and climate change, is presenting a fact that pure technical solution would never be the key to problems of ecological environment, and that ecological justice should be one aspect of a comprehensive justice.

\section{Economic Dimension}

Putting aside the causes of technological rationality, we now focus on the influence of the dual driving forces of economic rationality and political reason on the ecological environment. Only when considering the ecological issues combined with industrialization process and human civilization, one can get to the essence of the matter.

Marx's analysis (1996. P. 187) of the relation of human being and nature is enlightening. He presented in Das Kapital that Labor is, in the first place, a process in which both man and Nature participate, and in which man of his own accord starts, regulates, and controls the material re-actions between himself and Nature. Natural object is transformed by the production as a labor to an object that meets people's needs and has the use value. Human beings are connected with the nature through the media of labor, efficiently raising their own capability of commanding nature on one hand, and achieving self-fulfillment through the transformation of nature on the other hand. Nature and human beings associate through the labor as a practical activity, and develop harmonious relationship between them when the activity forms a virtuous cycle. However, the realistic situation is that human beings pursue with no limit the industrial modernization and profit expansion, grab the natural resource with absence of restraint, drain the land out of nutrition, and destroy the water quality. As a result, the pollution transferred back and forth between the nature and living community, when neither of which can afford the level of damage, the pollution begins to transfer worldwide during the process of globalization, thus causing catastrophic consequences.

Whether or not the situation can be limited and even reversed by human reason? However, the situation is exactly the inevitable consequence of human reason under capitalism.

In Marx's classic analysis of capitalist production and capital circulation, the occupation of the capitalists over labor and the pursuit for profit maximization are the roots of the unjust structure. In Das Kapital, Marx uses "the general formula of capital" (M-C-M') to analyze the entire logic of capitalism. Based on the general formula of capital, Capital (M) is used to purchase the labor force and the raw materials, then transformed by labor force to produce commodity $(\mathrm{C})$, which is sold later in the market. In the latter process, the commodity capital is transformed into monetary capital $\left(\mathrm{M}^{\prime}\right)$. According to the principle of exchange at equal value, value form could only be transformed between commodity and currency, but not arouse the change of value of commodities. While as we all know that the capitalist production indeed created the increment of value, which is known as $M^{\prime}=M+\Delta m$ and $\Delta \mathrm{g}$ is called surplus value. The raising up of surplus value touched the ground of capitalist production: the aim of capitalist production is not to satisfy the demands of people, but to complete the transition to generate profits which is the essential motivation of the capitalists. That's the reason why Marx (1996) said

The leap taken by value from the body of commodity, into the body of the gold, is, as I have elsewhere called it, the salto mortale of the commodity. If it falls short, then, although the commodity itself is not harmed, its owner decidedly is (p. 116).

The increase in capital and the appearance of surplus value reflect the deep social relation concealed by the things such as currency and commodity. The nature of the process, moreover, means that there is no end to the incentive of seeking more money or surplus value (Marx, 1996. P. 157) 
John Bellamy Foster profoundly pointed out that characteristic of monopoly capitalism in modern capitalism system is a further warping of this process through the displacement of natural-material use value by specifically capitalist use value-the only real "use" of which is to enhance exchange value for the capitalist. The logic gives birth to the logic of modern finance system that the capital appears to produce more capital, with even the fundamental production link no longer existed in many cases. The modern society built on the basis of capital accumulation is reconstructing the pyramids structure of society, and create in the new period a polarization between the rich and the poor. Capitalist logic leads to a paradox of modernization that ecological justice has profound contradiction with the current status of capitalist system.

\section{Political Dimension}

In capitalist countries, politicians make beautiful and empty promises to the voters, while high level of welfare and social wealth is necessarily required to maintain the stability of governance. Therefore, the capitalists have to constantly create the demand of consumption of labors to increase their capability and desire of purchase so as to meet their aims. On the other hand, the economic rationality has driven the capitalists to exploit labors with high-tech methods and injustice social structures, which has resulted in that workers may get more incomes while their living condition degrades. Hence, the contradictions between the capital demand of enormous profits and the creation of welfare for the legality of politics is intensified and irreconcilable. To appease the conflict as possible, the capitalists have to strengthen their exploitation of natural resources to seek for additional material wealth, which would definitely leads to environmental damage and ecological crisis. David Pepper (1993), the third generation of the representatives of Ecological Marxism said "Not only are crises such as inflation, depression, the imbalance between production and need, and environmental degradation needed by capitalism, they are also an inevitable outcome of the system (p. 82). "The issue of ecological crisis has sharply revealed that the so-called legality of Capitalism is established on the maximum of profits and damage of the ecological system. As James 0'Connor (1997) criticized, if we have made rational and democratic ecological and economic regulations in the past two centuries, the Capitalism that we know may never exist.

Based on a political consideration, the chain of capitalist industrial production with the nature of profit pursuit entangles human beings and nature, and distorts the originally harmonious relationship between them. The resulting environmental destruction and ecological deterioration have direct impact on the daily life of local citizens. Therefore, in order to keep political correctness at elections and maintain a global appeal to the political system, transferring the environmental problems abroad has becomes the only way for capitalist countries developed to a certain stage.

Globalization is exacerbating the ecological crisis. Marx (1976) analyzes that "the bourgeoisie has through its exploitation of the world market given a cosmopolitan character to production and consumption in every country (p. 488). "It is the formation of word market and the close connection of global economy that break the unbalanced distribution of capital, source of raw materials and consumer markets. In the process of economic globalization, world factory has provided more and more possibilities of productive cooperation and labor relations, while diverse products and technological modes offer a great number of options and choices. Capitalism has redeployed the resources all over the world and transferred the industries with high level of energy consumption and pollution into the developing countries. Seemingly, it may ease the dissatisfaction of domestic citizens, but it is quite unjust globally. With the effect of price scissors, ecological crisis problems migrate on a large scale from developed countries, reassemble and burst out at developing countries, accompanied with accordingly increased global wealth disparities. In numerous environment and climate summits worldwide, developed countries always criticize devel- 
oped countries for ruining the ecological environment, hardly imaging that they are the very ones to blame.

The situation is essentially the result rendered by both economy and politics. What is reasonable from a neoclassical perspective (Lang and Mokrani, 2013) - production that takes place where it is economically most efficient - has pushed many countries into the new/old strategy of resource extractivism. The choices of developing countries exactly illustrate a survival paradox of human beings: people suffering in poverty and deprivation are unable to obtain the resources from capital accumulation, thus the inevitable outcome under the relatively rigid international order would be that one must exchange own natural and labour resources for the wealth from developed countries at the top of pyramid, so as to get away from poverty and inequality. In the so-called "equal" and "development" process, developed countries are paying a heavy price, which harms people's living circumstances and distorts the real essence of development.Howard Thomas Odum (1996) describes the dilemma as "an ecological exchange of inequality". Trade between the global north and the global south thus took the form of "imperial capitalism", in which rich nations gained at the expense of poor (p. 217).

\section{Rescuing Ecological Justice}

It is an inevitable trend that the capitalist economic and political structure drifts away from the harmonious co-existence between human and nature with a growing rift. Samir Amin (2013) proclaimed that the "capitalist economic rationality" has transformed into "social irrationality on the scale of the human race" and the earth as a whole (p. 55). There is an urgent need to make efforts to rescue the ecological justice.

First of all, ecological Marxism presents the comprehensive value of ecology and social justice. The realization of ecological justice is closely related to the justice of institution, economy or society, and is embodied in the justice of distribution of social resources, justice of economic development, and the justice of the relation between human being and nature. The development in harmony of the nature and society cannot be promoted in an appropriate way until the ecological justice is viewed in an overall consideration and then adopted in practice. James $0^{\prime}$ Connor (1997) said it is more and more clear that the justice of social economy and ecology are two sides of one historical process. If technological and economic rationality was maintained as the leading value, the ecological destruction would become even more serious and human beings would be alienated in the end in the process of transforming the outside world. On the contrary, if ecological justice was placed above all other types of justice, its legitimacy would be broken by practical ecological movements.Peter Wenz (1988) points out that the social justice and protection of environment should be paid attention to at the same time. Our natural environment is no longer suitable for living if it's lack of environmental protection. Our society is becoming hostile if it's lack of justice. Therefore, the emphasis of ecology shall not dominate or rise above the concerns of justice, while the pursuit of justice is definitely not neglect the impact on environment.

Second, new values and view of nature must be constructed. To some extent, the attitude of people to treat the environment reflected the process of civilization of the society. The extent to which people emphasize the ecological justice highly depends on the level of the understanding of justice, and on how people would apply justice to the areas outside the world of the subject of human being. Daniel Goleman (1994) concludes that the deep reason of environmental crisis is the so-called Anthropocentrism in the modern world, but the egocentrism and the world view of instrumentalism. The revolution of ecological philosophy has evoked the deep revolution and change of people's value. The raising up of the philosophical concepts such as "animal rights theory", "Biocentrism" and "Eco-centrism" urged people to emphasize the intrinsic value and rights of the natural resources, which presented that nature did not only have instrumental value for human 
being, but also have its independent intrinsic value. Therefore, it is necessary for people to restrain their behaviours and attitudes towards the nature, while at the same time to take the moral responsibilities for the nature so as to realize the harmonious coexistence of human society and the biosphere.

Marx's arguments (1975) reflected a cultural attitude, Nature is man's inorganic body - nature, that is, in so far as it is not itself human body. Man lives on nature means that nature is his body, with which he must remain in continuous interchange if he is not to die. That man's physical and spiritual life is linked to nature means simply that nature is linked to itself, for man is a part of nature (p. 276).

As a social existence, human being is first of all a natural existence, both of which are in harmonious unification. From the aspect of natural existence to understand the social existence would provide a perspective to comprehend the relation of human being and nature. The following text of Marx (1975) further increases the relation to a higher level of human civilization:

In this natural species-relationship man's relation to nature is immediately his relation to man, just as his relation to man is immediately his relation to nature - his own natural destination. In this relationship, therefore, is sensuously manifested, reduced to an observable fact, the extent to which the human essence has become nature to man, or to which nature to him has become the human essence of man. From this relationship one can therefore judge man's whole level of development (p. 296).

In The Grundrisse, Marx (1986) writes in a more systematic and mature way with the analysis of "three formations of society" (p. 95): In the first formation, "human productivity develops only to a limited extent and at isolated points"; In the second formation, "a system of general social exchange of matter, a system of universal relations, universal requirements and universal capacities, formed", whose character is that "personal independence based upon dependence mediated by things". Then in the third one, "Free individuality, based on the universal development of individuals and on their subordination of their communal, social productivity, which is their social wealth." It can be seen that the development of human society is premised on the basis of its dependence mediated by things, and improves itself and manifests its activeness through the transformation of nature by human beings. When the society is developed to the third form that our practical ability and the social productivity forces have reached an unprecedented level, it never means that the acknowledgement of the dependence mediated by things would be abandoned but rather that a new situation of harmonious co-existence between human and nature would be established with us deepening of understanding and advance in transformation capability. By then, human beings will bring the bearing capacity and sustainability of nature into their own development at the same time of meeting their own demands and achieving full development, that is, human needs coincide with nature needs.

Third, the environmental movement stimulates social changes. Environmental activism that accords with the principle of ecological justice emerges with an aggressive stance, dramatically shaking and collapsing the value criterions that have been internalized in our ideas for long, and it challenges people's postmodernism style of resting on the things as they are and enjoying the pleasure and satisfaction. Throughout this development process, ecological philosophy is always the precursor in thinking. For example, ecological Marxism maintains the use of historical materialism as the tool for the analysis and criticism on the capitalist system, and suggests saving the ecological crisis in a tight corner by energizing radical ecological movements, which plays an essential role in helping people to see through the appearance of ecological problems to the essence of capitalist system. Although we could not conclude the movement in China was inspired by Ecological Marxism, the thoughts of the value originated from the theoretical development are essential. The mass protest in 2012 in Qidong and Shifang in China successfully impacted and 
changed the policy making of local government on the environmental issue, marking a milestone event in the development process of civil society in China.

Meanwhile, the rise of ecological movement comes down in one continuous line with the anti-globalism. Globalization on one hand propels the developed countries to be the biggest beneficiaries, and on the other hand results in a series of global justice issues such as environment contamination and wealth polarization in a great many developed countries that are passively involved in. Unrestricted free trades and investments cause the spread of pollution throughout the world, which intensifies the exhaustion and degeneration of resources, and threatens the sustainable development of globalization. Thus, antiglobalism is closely associated with the booming globalization.

\section{Conclusion}

Ecological environment is the largest public goods in the world. Human beings share the ecological resources, are unable to specifically define the responsibility boundaries on ecological issues, which is the centralized reflection of integrity of human rights and responsibilities. Ecological issues require all countries' cooperation with a common effort, otherwise it will be the weakness of development of global society and economy, and will eventually cause permanent damage to the human society. This is an overall matter of ecology, justice and modernization, with complicated and deep connections and conflicts among them, thus it is also a far-reaching comprehensive historical transformation. John Bellamy Foster (2013) has indicated that "an urgent necessity for the world today is therefore to develop an understanding of the interconnections between the deepening impasse of the capitalist economy and the rapidly accelerating ecological threat-itself a by-product of capital development."

Ecological issue requires a principle of justice, which prompts us to carry out global construction reform, the spirit of which substantially lead to the essence of Marx. As it is raised up in the Rio +20 Conference, if we could not embrace ecology with the social economy, global order and economic structure, if we could not complete the revolution of values and ideas, the ecological development and economic structure will have everlasting conflicts and the Green Economy will be a realistic Utopia. Therefore, the realization of reform would be the way out of the dilemma.

The United Nations Environment Programme (UNEP) issued a comprehensive report (2011) in which it shows that the green economy is aided by "widespread disillusionment with our prevailing economic paradigm, a sense of fatigue emanating from the many concurrent crises and market failures experienced during the very first decade of the new millennium, including especially the financial and economic crisis of 2008".

But at the same time, we have seen increasing evidence of a way forward, a new economic paradigm - one in which material wealth is not delivered perforce at the expense of growing environmental risks, ecological scarcities and social disparities." This prompted us to be full of hope for the undergoing and long lasting economic transformation and reform.

Being hopeful while bristled with difficulties, we are seemingly full of confidence but hesitating to move forward sometimes. The path to the future is extremely clear once people are willing to change. Foster (2002) has indicated a possible direction: our most serious environmental problems can be overcome without abandoning the prospect of human progress-but only if we are willing to carry out fundamental social change, in such a way as to make a more sustainable relation to the environment possible (p. 7).

\section{ЛИTEPATYPA/REFERENCES}

Marx K. and Engels F. (1975). Collected Works, vol. 3. Moscow: Progress Publishers. (In Russian.)

Marx K. and Engels F. (1976). Collected Works, vol. 6. Moscow: Progress Publishers. (In Russian.) 
Marx K. and Engels F. (1980). Collected Works, vol. 14. Moscow: Progress Publishers. (In Russian.)

Marx K. and Engels F. (1986). Collected Works, vol.28. New York: International Publishers. (In Russian.)

Amin S. (2013). Three essays on Marx's Value Theory. New York: Monthly Review Press. Beck U. (1992). Risk Society: Towards a New Modernity. London: SAGE.

Coleman D. (1994). Ecopolitic: Building a Green Society. New Brunswick: Rutgers University Press. Press.

Foster J.B. (2000). Marx's Ecology: Materialism and Nature. New York: Monthly Review

Foster J.B. (2002). Ecology against Capital. New York: Monthly Review Press.

Foster J.B. (2013). The Epochal Crisis. Monthly Review, 65 (5), 1-12.

Gorz A. (2011). Critique of Economic Reason. London: Verso.

Gorz A. (2013). Capitalism, Socialism, Ecology. London: Verso.

Grundmann R. (2001). Transnational Environmental Policy: Reconstructing Ozone. New York: Routledge Press.

Lang M. and Mokrani D. (2013). Beyond Development. Alternative visions from Latin America (http://rosalux-europa.info/userfiles/file/Beyond_Development_RLS_TNI_2013.pdf) Marcuse H. (1971). Counter revolutionary and Revolt. Boston: Beacon.

Marx K. and Engels F. (1996). Collected Works, vol. 35. New York: International Publishers.

O'Connor J. (1997). Natural Causes: Essays in Ecological Marxism. London: The Guilford Press.

Odum H.T. (1996). Environmental Accounting. New York: John Wiley and Sons.

Pepper D. (1993). Eco-Socialism: From Deep Ecology to Social Justice. London: Routledge.

UNEP (2011). Green Economy Initiative (http://www.unep.org/greeneconomy/)

Wenz P.S. (1988). Environmental Justice. New York: SUNY. 